\title{
Association of hematology profile with serum 25-hydroxy vitamin D and Bsml polimorphism in community-dwelling older adults
}

\author{
Associação do perfil hematológico com os \\ niveis séricos de 25-hidroxivitamina $D e$ \\ polimorfismo BsmI de idosos não \\ institucionalizados
}

\author{
Alexandre Sérgio SILVA ${ }^{1}$ \\ Chahira Taha Mahd Ibrahim ISSA ${ }^{1}$ \\ Dayanna Joyce Marques QUEIROZ1 \\ Darlene Carmati PERSUHN² \\ Eduarda Pontes dos Santos ARAÚJO' \\ Maria da Conceição Rodrigues GONÇALVES ${ }^{1}$
}

A B S T R A C T

\section{Objective}

To investigate the association between serum level of 25-hydroxy vitamin D and the Vitamin D Receptos gene Bsml polymorphism in the blood profile of community-dwelling older adults.

\section{Methods}

This cross-sectional study included 142 older males and females. A questionnaire collected socio demographic information, medical history, and factors associated with sun exposure. Weight, height, and waist circumference were measured. Biological material was collected to analyze biochemical parameters 25-hydroxy vitamin D, parathormone, serum calcium, urea, creatinine, liver enzymes, and blood profile) and to verify the presence of the vitamin D receptos gene Bsml polymorphism.

\section{Results}

Most participants were female (80.3\%). The mean levels of 25-hydroxy vitamin D, hemoglobin, and hematocrit were $32.1 \pm 7.3 \mathrm{ng} / \mathrm{dL}, 13.5 \pm 1.5 \mathrm{~d} / \mathrm{dL}$, and $40.0 \pm 4.4 \%$, respectively. Fifty-eight $(40.8 \%)$ participants had vitamin

\footnotetext{
${ }^{1}$ Universidade Federal da Paraíba, Centro de Ciências da Saúde, Pós-Graduação em Ciências da Nutrição. Campus I, Cidade Universitária, s/n., Castelo Branco, 58051-900, João Pessoa, PB, Brasil. Correspondência para/Correspondence to: AS SILVA. E-mail: <alexandresergiosilva@yahoo.com.br>.

2 Universidade Federal da Paraíba, Centro de Ciências Exatas e da Natureza, Pós-Graduação em Biologia Celular e Molecular. João Pessoa, PB, Brasil.
} 
D insufficiency/deficiency $(25.7 \pm 3.3 \mathrm{ng} / \mathrm{mL})$, and $18(12.6 \%)$ had anemia. Serum vitamin D was associated with hemoglobin $(p=0.030)$ and hematocrit $(p=0.032)$. However, when subjects were categorized as anemic or not anemic, said association was not maintained $(p=0.270)$. Moreover, the Bsml polymorphism was not associated with hemoglobin and hematocrit levels, regardless of vitamin D status.

\section{Conclusion}

The serum level of vitamin $D$ is associated with hematocrit and hemoglobin levels in older adults. However, these blood parameters were not associated with the vitamin D receptor gene Bsml polymorphism.

Keywords: Anemia. Aged. Hemoglobins. Polymorphism. Vitamin D.

\section{RE S U M O}

\section{Objetivo}

Investigar a associação do perfil hematológico com os niveis séricos de 25-hidroxivitamina D e polimorfismo Bsml do gene vitamina D receptor de idosos não institucionalizados.

\section{Métodos}

Estudo transversal realizado com 142 idosos de ambos os sexos. Foram coletadas, por meio de um questionário, informações sociodemográficas, antecedentes clínicos e fatores associados à exposição solar. Além disso, foram aferidas medidas antropométricas de peso, altura e circunferência da cintura. Material biológico foi coletado para análise dos parâmetros bioquímicos (25-hidroxivitamina D, parathormone, cálcio sérico, ureia, creatinina, enzimas hepáticas e perfil hematológico) e para identificação do polimorfismo Bsm/ do gene vitamina D receptor.

\section{Resultados}

Os participantes do estudo eram, em sua maioria, do sexo feminino (80,3\%) e apresentaram concentrações médias de 25-hidroxivitamina $D$, hemoglobina e hematócrito de 32,1 $\pm 7,3 \mathrm{ng} / \mathrm{dL}, 13,5 \pm 1,5 \mathrm{~d} / \mathrm{dL}$ e 40,0 $044 \%$, respectivamente. Da amostra total, 40,8\% (n=58) apresentaram insuficiência/deficiência de vitamina $D$ $(25,7 \pm 3,3 \mathrm{ng} / \mathrm{mL})$ e 12,6\% (n=18), anemia. Encontrou-se associação entre as concentrações séricas de vitamina $D$ com as de hemoglobina $(p=0,030)$ e hematócrito $(p=0,032)$. Entretanto, quando os sujeitos foram categorizados quanto à presença ou não de anemia, essa associação não se manteve $(p=0,270)$. Além disso, não foi observada relação entre o polimorfismo Bsml e as concentrações de hemoglobina e hematócrito nos grupos de idosos com suficiência ou insuficiência/deficiência de vitamina D.

\section{Conclusão}

O presente estudo encontrou associação entre as concentrações séricas de vitamina $D$ e as de hematócrito e hemoglobina nos idosos analisados. Contudo, não foram observadas associações entre esses parâmetros hematológicos e o polimorfismo Bsml do gene vitamina $D$ receptor.

Palavras-chave: Anemia. Idoso. Hemoglobina. Polimorfismo. Vitamina D.

\section{INTRODUCTION}

Vitamin D deficiency and anemia are two conditions that have been frequently investigated and reported in the literature in many populations and age groups ${ }^{1,2}$. In older adults the incidences of anemia are estimated to be around $11 \%$ in men and $10 \%$ in women ${ }^{3}$. Similarly, there are many literature reports of high prevalences of vitamin $D$ insufficiency/deficiency in this population ${ }^{4,5}$.
Vitamin D has an important role in bone health. However, in the last years, an important body of evidence has associated this metabolite with many extraskeletal outcomes, such as diabetes, cancer, and metabolic syndrome ${ }^{6}$. More recently, observational studies reported a relationship between vitamin $D$ level and hemoglobin in many populations, especially in older adults ${ }^{7-10}$.

The possible action of vitamin $D$ in the proliferation and differentiation of a variety of 
cells, among them hematopoietic stem cells, and its action on erythropoiesis have been investigated ${ }^{11}$. In this sense, an adequate level of 25-Hydroxy Vitamin D $(25(\mathrm{OH}) \mathrm{D})$ seems to be crucial for the normal production of red blood cells, although the pathophysiological mechanisms still need to be fully elucidated ${ }^{12}$. Additionally, the finding that many body tissues, such as the bone marrow ${ }^{13,14}$, have Vitamin D Receptors (VDR), a protein responsible for gene transcription and for carrying out cell function in many tissues, reinforces the hypothesis that there is a positive relationship between vitamin $\mathrm{D}$ level and hemoglobin $7,15,16$, and that this phenomenon may be influenced by VDR gene polymorphisms ${ }^{17-19}$. Single-nucleotide polymorphisms are common in the human genome, and frequently, they occur in specific genes involved in the genesis of and predisposition to many human diseases. The most common VDR gene polymorphisms occur between exons 8 and 9, such as Apal, Bsml, and $\mathrm{Taq}^{20}$.

Despite the great interest on the role of vitamin $\mathrm{D}$ on the pathogenesis of many diseases, the relationship between vitamin D insufficiency/ deficiency and blood profile, and the physiological mechanisms of its activity are still controversial and based on a limited number of studies. Until now only two studies included a population of older adults without chronic diseases ${ }^{7,16}$, and none of them investigated their relationship with genetic characteristics. Thus, the present study aimed to investigate the association of serum level of 25(OH)D with the VDR gene Bsml polymorphism and the blood profile of community-dwelling older adults from a metropolis in the Brazilian Northeast region.

\section{METHODS}

This epidemiological and cross-sectional study included a random and representative sample of community-dwelling older adults aged at least 60 years. The participants were recruited at the Programa de Atenção à Pessoa Idosa (PAPI,
Care Program for the Elderley) in the city of João Pessoa (PB), a metropolis located in the Brazilian Northeast region. Data were collected between October 2012 and September 2013. In the study region, the four seasons are not well defined since the region has summer characteristics year round, with some months having more rain and cloudy days, which rarely last all day, and a temperature range of $23^{\circ}$ to $34^{\circ} \mathrm{C}$.

This study stems from a research project designed to investigate the prevalence of hypovitaminosis $D$ in a population of older adults, factors that affect this prevalence, and outcomes of this condition on cardiometabolic health. The sample size was calculated based on an estimated prevalence of hypovitaminosis D of 33\%, an error margin of $11 \%$, reliability of $95 \%$, design effect of 2.0, and an additional $5 \%$ to compensate for losses ${ }^{4}$. The minimum sample size should be 141 individuals. Of the 148 selected individuals, six were excluded, totaling 142 older adults who agreed to participate in the study.

The inclusion criteria were the absence of factors capable of affecting the level of vitamin D (use of supplements containing vitamin D and anticonvulsive or anti-HIV/AIDS [Human Immunodeficiency Virus/Acquired Immunodeficiency Syndrome] pharmaceuticals) and absence of any of the following conditions: nephrotic syndrome, acute or chronic renal failure, hepatic disease, hypo- or hyperthyroidism, wasting, or chronic alcohol or cigarette use.

The study was approved by the Research Ethics Committee of the Center of Health Sciences of Universidade Federal da Paraíba (Federal University of Paraíba) under protocol n 0374/12. The study procedures complied with Resolution $n^{\circ} 466 / 12$ of the Conselho Nacional de Saúde/ Ministério da Saúde (National Health Council/ Ministry of Health).

First the participants were clinically assessed and answered a questionnaire about their history of chronic diseases and surgeries, chronic use of pharmaceuticals, mean time of sun exposure, and use of long clothes and sunscreen. The 
questionnaire was administered by trained researchers. To avoid memory bias, the older adults answered the questionnaire accompanied by individuals who lived in the same household.

Nutritional assessment of Body Mass Index (BMI) was given by dividing weight by the square of the height ${ }^{2}$. Waist Circumference was measured by an inelastic tape measure with the individual standing up. The measurement was taken at the midpoint between the lowest rib and iliac crest. Body Mass Index and waist circumference were classified as recommended by the World Health Organization ${ }^{21}$. All measurements were taken three times and averaged.

Biochemical assessment of participants were instructed to fast for 12 hours. Blood count, calcium, urea, creatinine, alanine transaminase, and aspartate transaminase were determined by commercial kits (Labtest, Minas Gerais, Brazil), according to the manufacturer's instructions and automatic analyzer LabMax premium (Lagoa Santa-MG, Brazil). All analyses were performed twice. Parathormone (PTH) and 25(OH)D were determined by chemiluminescence. The intra- and inter-assay coefficients of variation were 13 and $15 \%$, respectively.

The reference values used were those suggested by Labtest. Normal urea was defined as 15 to $45 \mathrm{mg} / \mathrm{dL}$ for men and women, and serum creatinine, as 0.8 to $1.2 \mathrm{mg} / \mathrm{dL}$ for men and $0.6 \mathrm{mg}$ to $1.0 \mathrm{mg} / \mathrm{dL}$ for women. Kidney function was also estimated by creatinine clearance, using serum creatinine in the formula suggested by Cockcroft \& Gault ${ }^{22}$. Inadequate kidney function was defined as reference values $<60 \mathrm{~mL} / \mathrm{min} / 1.73 \mathrm{~m}^{2}$. Normal liver function was defined as alanine transaminase values of 11 to 45 (U/L) for men and 10-37 (U/L) for women; and aspartate transaminase values of 11 to 39 (U/L) for men and 10 to 37 (U/L) for women. Normal serum calcium was defined as $4.0-5.0 \mathrm{mg} / \mathrm{dL}$.

Anemia was defined as hemoglobin $<12 \mathrm{~g} / \mathrm{dL}$ for women and $<13 \mathrm{~g} / \mathrm{dL}$ for men, as recommended by the $\mathrm{WHO}$ and considering the reference values for older adults.
Serum 25(OH)D was classified as recommended by the Endocrine Society ${ }^{2}$ as follows: Sufficient (SUF) when serum vitamin $D$ $\geq 30 \mathrm{ng} / \mathrm{dL}$, insufficient when $29 \geq$ serum vitamin $D \geq 21$; and Deficient (DEF) when serum vitamin $\mathrm{D}<20 \mathrm{ng} / \mathrm{dL}$. The study older adults classified as insufficient and DEF were grouped together in a group called INSUF/DEF. The reference values for PTH were $15.0-65 \mathrm{pg} / \mathrm{dL}$

\section{Determination of the VDR gene Bsml genotype}

Cell samples from the oral epithelium were obtained by mouthwash with a 3\% sucrose solution. The genomic DNA was extracted as described elsewhere ${ }^{23}$. The VDR gene Bsml genotype was determined by Restriction Length Polymorphism Analysis of Polymerase Chain Reaction-Amplified Fragments (PCR/RFLP), using the primers 5'-CAACCAAGACTACAAGTACC GCGTCAGTGA-3' and 5' AACCAGCGGGAAG TCAAGGG-3'.

The annealing temperature was $58^{\circ} \mathrm{C}$. A 12-hour digestion stage at $37^{\circ} \mathrm{C}$ was conducted for an initial fragment of 870 base pairs (bp) using the enzyme Bsml. The result was verified by $1.5 \%$ agarose gel electrophoresis. This enzymatic digestion process did not cleave the B allele, which remained with $870 \mathrm{bp}$. The restriction site generated two fragments of 640 and $230 \mathrm{bp}$ (b allele). Figure 1 represents this procedure. The Bsml polymorphism was analyzed in 126 individuals, but 16 samples were lost because of DNA extraction or amplification problems.

The data were expressed as percentage, mean, and standard deviation of the mean. All variables were tested for normality and homogeneity by the Kolmogorov-Smirnov test. Intergroup differences were tested by the independent $t$-test or its non-parametric correspondent, the Mann-Whitney test. Bivariate analysis tested the statistical associations between the blood count variables and vitamin D of the 


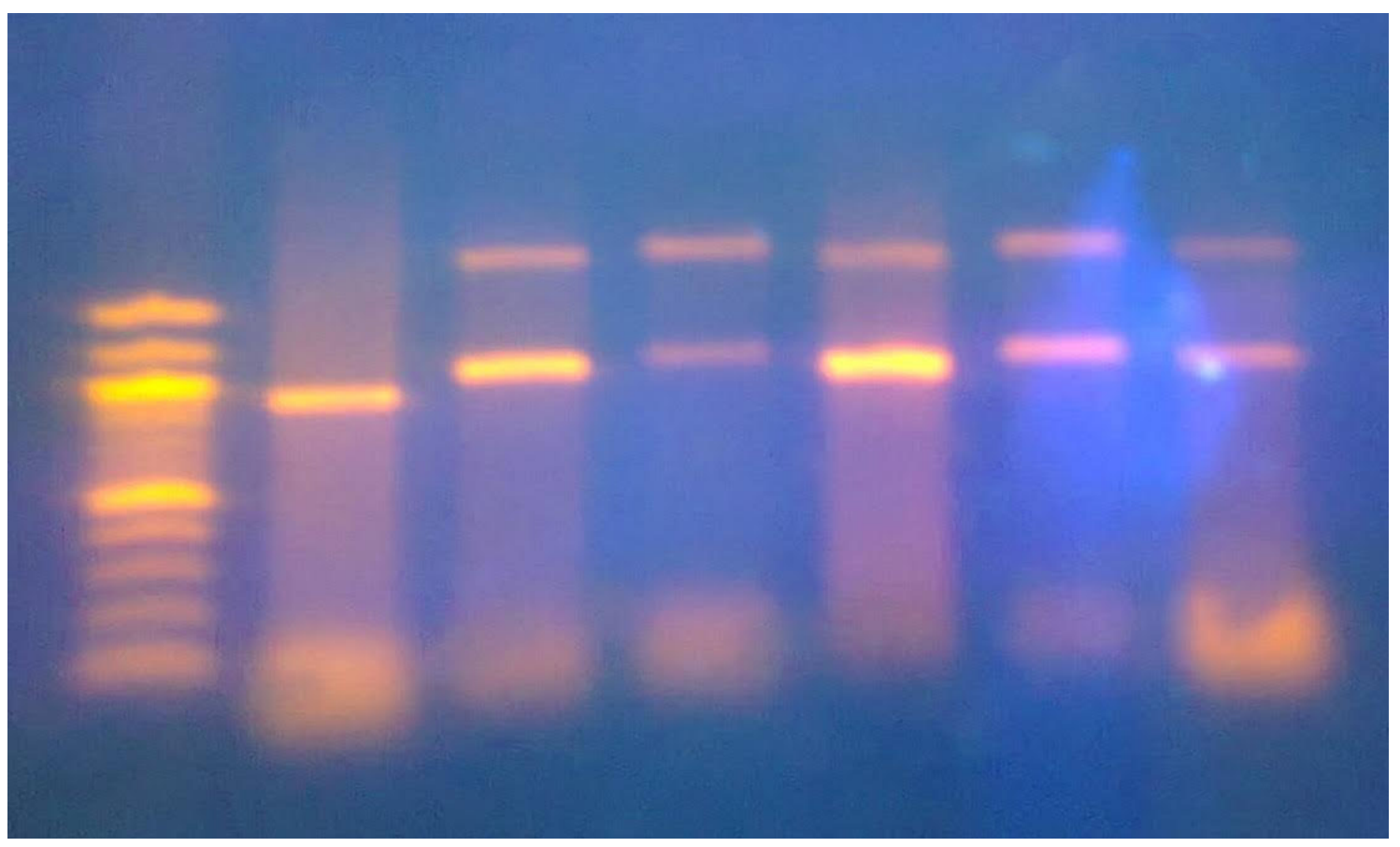

Figure 1. Agarose gel image. The procedure was conducted with a $870 \mathrm{bp}$ fragment. The restriction enzyme generated two fragments of $640 \mathrm{bp}$ and $230 \mathrm{bp}$, respectively.

groups SUF and INSUF/DEF, using the Spearman's chi-square test and Pearson's correlation coefficient. One-way Analysis of Variance (ANOVA) compared the means of the groups categorized by polymorphism. All statistical analyses were performed by the software Statistical Package for the Social Sciences (SPSS Inc., Chicago, llinois, United States) version 21, using a significance level of $5 \%$.

\section{RES U LT S}

The sample consisted of 142 older adults with a mean age of 69.9 years. Most participants were female (Table 1), and most had excess weight based on the WHO criteria. All groups had similar means.

The entire sample's mean serum level of $25(\mathrm{OH}) \mathrm{D}$ was in the normal range (mean of $32.1 \mathrm{ng} / \mathrm{dL}$ ). However, a significant part (40.84\%) of the sample had serum $25(\mathrm{OH}) \mathrm{D}<30 \mathrm{ng} / \mathrm{dL}$, so they were included in the INSUF/DEF group. Most individuals in this group were female. The PTH and calcium levels of both groups were similar. However, serum calcium levels were close to the lower limit of normality in the INSUF/DEF group. The renal and hepatic functions of the groups did not differ (data not shown). Moreover, the sample had a $12.6 \%$ prevalence of anemia.

Table 2 shows the blood count. The INSUF/ DEF group had significantly lower levels of hemoglobin and hematocrit than the SUF group, and these values were positively correlated with the level of 25(OH)D $(0.177$ and 0.180 , respectively). Nevertheless, the mean hemoglobin of both groups was within the normal range. The groups did not differ with respect to red cell, white cell, and platelet counts.

Regarding the positive relationship of vitamin D with hemoglobin and hematocrit, screening of the SUF and INSUF/DEF groups for anemia did not confirm this correlation (Table 3).

Analysis of variance showed that the polymorphism did not affect serum vitamin $D$ 
Table 1. Characterization of the sample and relationship of serum level of vitamin $D$ with the sociodemographic and biochemical data of community-dwelling older adults. João Pessoa (PB), Brazil, 2013.

\begin{tabular}{|c|c|c|c|c|c|c|c|c|c|c|}
\hline \multirow{2}{*}{ Variables } & \multicolumn{3}{|c|}{ General $(n=142)$} & \multicolumn{3}{|c|}{$25(\mathrm{OH}) \mathrm{D}^{*}$ SUF $(n=84)$} & \multicolumn{3}{|c|}{$25(\mathrm{OH}) \mathrm{D}^{* *}$ INSUF/DEP $\mathrm{s}(\mathrm{n}=58)$} & \\
\hline & \multicolumn{2}{|c|}{ Prevalence (\%) } & $\mathrm{n}$ & \multicolumn{2}{|c|}{ Prevalence (\%) } & $\mathrm{n}$ & \multicolumn{2}{|c|}{ Prevalence (\%) } & \multicolumn{2}{|l|}{$\mathrm{n}$} \\
\hline \multicolumn{11}{|l|}{ Gender } \\
\hline Male & \multicolumn{2}{|c|}{19.7} & 28 & \multicolumn{2}{|c|}{28.6} & 24 & \multicolumn{2}{|c|}{6.9} & 4 & \\
\hline Female & \multicolumn{2}{|c|}{80.3} & 114 & \multicolumn{2}{|c|}{71.4} & 60 & \multicolumn{2}{|c|}{93.1} & 54 & \\
\hline \multicolumn{11}{|l|}{ Skin color } \\
\hline White & \multicolumn{2}{|c|}{35.9} & 51 & \multicolumn{2}{|c|}{32.1} & 27 & \multicolumn{2}{|c|}{41.4} & 24 & \\
\hline Brown & \multicolumn{2}{|c|}{45.1} & 64 & \multicolumn{2}{|c|}{45.3} & 38 & \multicolumn{2}{|c|}{44.8} & 26 & \\
\hline \multirow[t]{2}{*}{ Black } & \multicolumn{2}{|c|}{19.0} & 27 & \multicolumn{2}{|c|}{22.6} & 19 & \multicolumn{2}{|c|}{13.8} & 8 & \\
\hline & M & SD & & $\mathrm{M}$ & SD & & M & SD & & ${ }^{t} p$ \\
\hline Age (years) & 69.9 & 7.0 & & 70.1 & 7.2 & & 69.5 & 6.9 & & 0.601 \\
\hline BMI $\left(\mathrm{kg} / \mathrm{m}^{2}\right)$ & 28.3 & 4.4 & & 28.4 & 4.4 & & 28.1 & 4.7 & & 0.735 \\
\hline Sun exp (min) & 52.3 & 44.0 & & 58.0 & 49.0 & & 44.0 & 34.4 & & 0.141 \\
\hline $25(\mathrm{OH}) \mathrm{D}(\mathrm{ng} / \mathrm{ml})$ & 32.1 & 7.3 & & 36.5 & 5.8 & & 25.7 & 3.3 & & 0.000 \\
\hline PTH & 42.2 & 23.7 & & 42.6 & 27.0 & & 41.6 & 18.1 & & 0.818 \\
\hline Calcium (mg/dL) & 8.8 & 1.1 & & 9.0 & 1.1 & & 8.6 & 1.2 & & 0.806 \\
\hline
\end{tabular}

Note: ${ }^{*} 25(\mathrm{OH}) \mathrm{D}$ e" $75 \mathrm{nmol} / \mathrm{L}(30 \mathrm{ng} / \mathrm{mL}) ;{ }^{* *} 25(\mathrm{OH}) \mathrm{D}<75 \mathrm{nmol} / \mathrm{L}(30 \mathrm{ng} / \mathrm{mL}) ;{ }^{\dagger} p$-values of the comparison between the groups of older adults with sufficient and insufficient/deficient $25(\mathrm{OH}) \mathrm{D}$ according to the independent Student's $t$-test.

The data are expressed as Mean (M) and Standard Deviation (SD) of the mean.

25(OH)D: 25-Hydroxy Vitamin D; Sun exp: Sun Exposure in Minutes; BMI: Body Mass Index; PTH: Parathormone.

Table 2. Relationship between vitamin D level and the blood count of older adults from nine PAPI community groups in João Pessoa (PB), Brazil, 2013.

\begin{tabular}{|c|c|c|c|c|c|c|c|c|}
\hline \multirow[t]{2}{*}{ Variables } & \multicolumn{2}{|c|}{ General $(n=142)$} & \multicolumn{2}{|c|}{$25(\mathrm{OH}) \mathrm{D}^{*}$ SUF $(\mathrm{n}=84)$} & \multicolumn{2}{|c|}{$\begin{array}{c}25(\mathrm{OH}) \mathrm{D}^{* *} \text { INSUF/DEP } \\
(\mathrm{n}=58)\end{array}$} & \multirow[t]{2}{*}{$p^{\dagger}$} & \multirow{2}{*}{$\begin{array}{l}\text { Correlation test } \\
\qquad p^{t+}(r)\end{array}$} \\
\hline & Mean & SD & Mean & SD & Mean & SD & & \\
\hline Hemoglobin (g\%) & 13.50 & 1.4 & 13.7 & 1.4 & 13.2 & 1.4 & 0.030 & $0.035(0.177)$ \\
\hline Erythrocytes $\left(\mathrm{mm}^{3}\right)$ & 4358.03 & 494.6 & 4457.9 & 529.7 & 4228.2 & 401.6 & 0.370 & \\
\hline Hematocrits (\%) & 40.00 & 4.4 & 40.7 & 4.5 & 39.0 & 4.0 & 0.031 & $0.032(0.180)$ \\
\hline $\mathrm{MCV}\left(\mathrm{u}^{3}\right)$ & 92.00 & 5.8 & 91.7 & 5.9 & 92.3 & 5.6 & 0.979 & \\
\hline $\mathrm{HCM}(\mathrm{Pg})$ & 31.10 & 2.0 & 30.9 & 2.1 & 31.2 & 1.8 & 0.913 & \\
\hline CHCM (\%) & 33.80 & 1.1 & 33.7 & 1.1 & 33.9 & 1.0 & 0.894 & \\
\hline Leucocytes $\left(\mathrm{mm}^{3}\right)$ & 6426.00 & 1717.1 & 6504.7 & 1740.0 & 6389.6 & 1744.2 & 0.858 & \\
\hline Neutrophils (\%) & 55.80 & 8.1 & 56.8 & 8.4 & 54.4 & 7.7 & 0.204 & \\
\hline Eosinophils (\%) & 2.50 & 1.1 & 2.6 & 1.1 & 2.4 & 1.1 & 0.251 & \\
\hline Lymphocytes (\%) & 39.40 & 7.9 & 38.5 & 7.9 & 40.9 & 7.8 & 0.153 & \\
\hline Monocytes (\%) & 2.10 & 1.0 & 2.0 & 0.9 & 2.1 & 1.1 & 0.698 & \\
\hline Platelets & 211.80 & 54.3 & 209.2 & 49.8 & 217.0 & 60.1 & 0.560 & \\
\hline
\end{tabular}

Note: The data are expressed as mean and Standard Deviation (SD) of the mean.

${ }^{*} 25(\mathrm{OH}) \mathrm{D}$ e" $75 \mathrm{nmol} / \mathrm{L}(30 \mathrm{ng} / \mathrm{mL}){ }^{* *} 25(\mathrm{OH}) \mathrm{D}<75 \mathrm{nmol} / \mathrm{L}(30 \mathrm{ng} / \mathrm{mL}) ;{ }^{\dagger} p$-values of the comparison between groups of older adults with sufficient and insufficient/deficient levels of $25(\mathrm{OH}) \mathrm{D}$ according to the independent Student's $t$-test; ${ }^{\mathrm{tt}} \mathrm{C}$ Correlation between variables with significantly different p-value means of groups of older adults with sufficient and insufficient/deficient levels of 25(OH)D according to Pearson's correlation coefficient. 25(OH)D: 25-hydroxy vitamin D; MCV: Mean Corpuscular Volume; MCH: Mean Corpuscular Hemoglobin; MCHC: Mean Corpuscular Hemoglobin Concentration; M: Mean; SD: Standard Deviation.

(Table 4). Individuals with the BB, bb, or heterozygous $\mathrm{Bb}$ genotypes had statistically similar values of serum vitamin $D$, hemoglobin, and hematocrit. These results refer both to the entire sample and to the groups SUF and INSUF/ DEF. 
Table 3. Association of anemia with sufficient or insufficient/deficient vitamin D level in community-dwelling older adults. João Pessoa (PB), Brazil, 2013.

\begin{tabular}{|c|c|c|c|c|c|}
\hline \multirow{2}{*}{ Characteristics } & \multicolumn{2}{|c|}{ Patients with anemia } & \multicolumn{2}{|c|}{ Patients without anemia } & \multirow{2}{*}{$p^{\dagger}$} \\
\hline & $\mathrm{n}$ & $\%$ & $\mathrm{n}$ & $\%$ & \\
\hline $25(\mathrm{OH}) \mathrm{D}^{*}$ INSUF/DEF & 10 & 17.2 & 48 & 82.8 & \multirow{2}{*}{0.270} \\
\hline $25(\mathrm{OH}) \mathrm{D}^{* *}$ SUF & 8 & 9.2 & 76 & 90.5 & \\
\hline
\end{tabular}

Note: ${ }^{*} 25(\mathrm{OH}) \mathrm{D}<75 \mathrm{nmol} / \mathrm{L}(30 \mathrm{ng} / \mathrm{mL}) ;{ }^{* *} 25(\mathrm{OH}) \mathrm{D} \geq 75 \mathrm{nmol} / \mathrm{L}(30 \mathrm{ng} / \mathrm{mL}){ }^{\dagger} g \chi^{2}$ value.

Table 4. Relationship between the Bsml polymorphism and the blood parameters of older adults. João Pessoa (PB), Brazil, 2013.

\begin{tabular}{|c|c|c|c|c|c|c|c|}
\hline \multirow{2}{*}{$\begin{array}{l}\text { Polymorphisms } \\
\text { General }(n=126)\end{array}$} & \multicolumn{2}{|c|}{$\mathrm{BB} / \mathrm{Bb}^{*}$} & \multicolumn{2}{|c|}{$\mathrm{Bb}^{*}$} & \multicolumn{2}{|c|}{$b^{*}$} & \multirow[t]{2}{*}{$p^{\dagger}$} \\
\hline & $n=38$ & $(28.6 \%)$ & $n=42$ & $(33.3 \%)$ & $n=48$ & $(38.1 \%)$ & \\
\hline $25(\mathrm{OH}) \mathrm{D}(\mathrm{ng} / \mathrm{mL})$ & 32.8 & 7.1 & 33.4 & 8.3 & 30.0 & 6.4 & 0.0653 \\
\hline Hemoglobin (g\%) & 13.6 & 1.4 & 13.6 & 1.3 & 13.4 & 1.4 & 0.8448 \\
\hline Hematocrit (\%) & 40.2 & 4.4 & 40.0 & 3.8 & 39.6 & 4.5 & 0.8324 \\
\hline SUF 25(OH)D $(n=75)^{\star *}$ & $n=23$ & $(30.66 \%)$ & $\mathrm{n}=28$ & $(37.33 \%)$ & $n=24$ & $(32 \%)$ & \\
\hline $25(\mathrm{OH}) \mathrm{D}(\mathrm{ng} / \mathrm{mL})$ & 36.6 & 5.7 & 37.4 & 7.3 & 34.9 & 4.0 & 0.3140 \\
\hline Hemoglobin (g\%) & 13.8 & 1.4 & 13.9 & 1.3 & 13.5 & 1.4 & 0.4862 \\
\hline Hematocrit (\%) & 40.9 & 4.5 & 40.7 & 4.1 & 39.8 & 4.5 & 0.6446 \\
\hline INSUFIDEF 25(OH)D $(n=51)^{* * *}$ & $n=13$ & $(25 \%)$ & $\mathrm{n}=14$ & $(27 \%)$ & $n=24$ & $(47 \%)$ & \\
\hline $25(\mathrm{OH}) \mathrm{D}(\mathrm{ng} / \mathrm{mL})$ & 26.2 & 3.3 & 25.4 & 2.5 & 25.1 & 4.0 & 0.7112 \\
\hline Hemoglobin ( $\mathrm{g} \%$ ) & 13.1 & 1.2 & 13.0 & 1.0 & 13.4 & 1.5 & 0.5968 \\
\hline Hematocrit (\%) & 38.8 & 3.9 & 38.5 & 2.5 & 39.4 & 4.6 & 0.7752 \\
\hline
\end{tabular}

Note: ${ }^{*}$ Data expressed as Mean \pm Standard Deviation of the mean; ${ }^{* *} 25(\mathrm{OH}) \mathrm{D}<75 \mathrm{nmol} / \mathrm{L}(30 \mathrm{ng} / \mathrm{mL}) ;{ }^{* * *} 25(\mathrm{OH}) \mathrm{D} \geq 75 \mathrm{nmol} / \mathrm{L}(30 \mathrm{ng} / \mathrm{mL})$; $p^{\dagger}$ Analysis of variance; $n=$ individuals number.

SUF: Sufficient; 25(OH)D: 25-hydroxy vitamin D; INSUF/DEF: Insufficient/Deficient.

\section{I S C U S S I O N}

The data of the present study partly confirm the hypothesis of a positive association of serum vitamin $D$ with hemoglobin and hematocrit. However, anemia was not associated with vitamin $D$ insufficiency/deficiency in the study sample. Additionally, the VDR gene Bsml polymorphism was not associated with hematocrit and hemoglobin levels, regardless of vitamin $D$ level, thereby refuting our initial hypothesis.

Similar results have been reported in the literature. Patel et al. ${ }^{8}$ determined the levels of $25(\mathrm{OH}) \mathrm{D}, 1.25(\mathrm{OH}) \mathrm{D}$, and hemoglobin in 1,661 individuals with a mean age of 70 years and chronic renal failure. They found that vitamin $D$ deficiency was independently associated with lower hemoglobin levels and anemia in this specific situation. On the other hand, Coutard et al. ${ }^{24}$ investigated whether vitamin $\mathrm{D}$ deficiency was associated with anemia in 226 hospitalized older French aged $\geq 70$ years and found that although $67.7 \%$ and $53.5 \%$ of the anemic and non-anemic groups had vitamin $D$ deficiency $(p<0.04)$, this association disappeared after adjusting for albuminemia. The authors emphasized that their finding contradicts earlier studies that had not adjusted for confounders.

Meanwhile, Sim et al. ${ }^{25}$ found significant associations of vitamin D deficiency with higher risk of anemia and lower mean hemoglobin. Nonetheless, the authors pointed out that chronic renal failure was present in $65 \%$ of the 554 patients they studied, which may have confounded their results. Thus, although some pieces of evidence suggest an association between levels of 25(OH)D and hemoglobin, the literature is still divergent on the topic, so further studies are needed. 
Moreover, most studies that reported the association were conducted on population subgroups with specific clinical conditions that make them much more vulnerable to the development of anemia, such as chronic renal failure or terminal diabetics ${ }^{15}$, hospitalization ${ }^{24}$, disease ${ }^{26,27}$, HIV infection ${ }^{28}$, and congestive heart failure ${ }^{29}$.

Only two studies have assessed the association in older adults without known chronic disease, similar to our sample. In a cohort with 9,675 community-dwelling older adults, vitamin $D$ deficiency was independently associated with the prevalence of anemia ${ }^{7}$. Nevertheless, Hirani et al. ${ }^{16}$ concluded that serum $25(\mathrm{OH}) \mathrm{D}$ was not significantly associated with hemoglobin. A recent meta-analysis of 5,183 individuals concluded that vitamin $D$ increased the risk of anemia ${ }^{30}$. Along with our results, pieces of evidence indicate that vitamin $D$ deficiency may be associated with hematopoietic activity. Although the relationship between the presence of anemia and vitamin $D$ status in the study sample was not confirmed, the small sample size may have influenced the result. Therefore, more studies are necessary to determine how much vitamin $D$ is necessary to influence the blood profile.

Although the mechanism that associates vitamin $\mathrm{D}$ deficiency with anemia has not been completely elucidated, a possible justification would be that vitamin $\mathrm{D}$ decreases the production of proinflammatory cytokines and the antimicrobial peptide hepcidin (hormone that regulates systemic iron level ${ }^{31}$. Another mechanism possibly associated would regard the VDR in certain tissues, such as the bone marrow ${ }^{13,14}$. Thus, the presence of polymorphisms associated with the VDR gene could influence the serum levels of this metabolite in individuals with anemia. Yet, the present study did not find a statistically significant correlation between the three alleles (BB, Bb, bb), and the blood profile of older adults from the Brazilian Northeast region.

Few studies have attempted to investigate said association with the Bsml polymorphism, such as Sezer et al. ${ }^{18}$, who found that the BB genotype seemed to provide more protection against anemia. Likewise, Ertürk et al. ${ }^{27}$ found that the $\mathrm{Bb}$ and bb variants were associated with higher levels of hemoglobin in hemodyalisis patients. Amato et al. ${ }^{19}$ found that hemodyalisis patients with the BB genotype had lower hemoglobin levels. All studies mentioned above involved individuals with chronic disease, which may explain result discrepancy. Moreover, a specific polymorphism may have different patterns of association in different populations secondary to the various evolutionary lineages ${ }^{32}$.

The present study investigated only one VDR gene polymorphism. Therefore, future studies should not only investigate the role of other polymorphisms, but also other genes associated with vitamin $\mathrm{D}$ metabolism and hematopoietic activity that may be associated with blood profile changes in older adults. Furthermore, an important limitation of this study should be pointed out. The small number of individuals with anemia may have influenced data analysis. Although the study prevalence of anemia was similar to that reported in the literature $(12.6 \%)$, studies with larger samples of individuals with anemia or with larger samples in general should be conducted to reduce the error margin and determine the influence of vitamin D on blood profile.

\section{CONCLUSION}

The study older adults had a high prevalence of vitamin D insufficiency/deficiency. In addition, serum vitamin D level was associated with hematocrit and hemoglobin levels. Even so, this association disappeared when individuals were categorized according to anemia status. What is more, the VDR gene Bsml polymorphism was associated with the hematocrit and hemoglobin levels of older adults, regardless of vitamin D status.

\section{CONTRIBUTORS}

All authors contributed to the conception and design of the study, data analysis and final editing. 


\section{REFERE N CES}

1. Zakai NA, Katz R, Hirsch C, Shlipak MG, Chaves $\mathrm{PH}$, Newman $A B$, et al. A prospective study of anemia status, hemoglobin concentration, and mortality in an elderly cohort: The cardiovascular health study. Arch Intern Med. 2005; 165:2214-20.

2. Holick MF, Binkley NC, Bischoff-Ferrari HA, Gordon CM, Hanley DA, Heaney RP, et al. Evaluation, treatment, and prevention of vitamin $D$ deficiency: An Endocrine Society clinical practice guideline. J Clin Endocrinol Metab. 2011; 96(7):1911-30. http:// dx.doi.org/10.1210/jc.2011-0385

3. Guralnik JM, Eisenstaedt RS, Ferrucci L, Klein HG, Woodman RC. Prevalence of anemia in persons 65 years and older in the United States: Evidence for a high rate of unexplained anemia. Blood. 2004; 104(8):2263-8. http://dx. doi.org/10.1182/blood2004-05-1812

4. Neves JP, Silva AS, Morais LC, Diniz Ada S, Costa MJ, Asciutti LS, et al. 25-hydroxyvitamin D concentrations and blood pressure levels in hypertensive elderly patients. Arq Bras Endocrinol Metabol. 2012; 56(7):415-22. http://dx.doi.org/10. 1590/S0004-27302012000700002

5. Arantes HP, Kulak CA, Fernandes CE, Zerbini C, Bandeira F, Barbosa IC, et al. Correlation between 25-hydroxyvitamin D levels and latitude in Brazilian postmenopausal women: From the arzoxifene generations trial. Osteoporos Int. 2013; 24(10):270712. http://dx.doi.org/10.1007/s00198-013-2407-5

6. Lichtenstein A, Ferreira-Júnior M, Sales MM, Aguiar FB, Fonseca LAM, Sumita NM, et al. Vitamina D: ações extraósseas e uso racional. Rev Assoc Med Bras. 2013; 59(5):495-506. http://dx.doi.org/10. 1016/j.ramb.2013.05.002

7. Perlstein TS, Pande R, Berliner N, Vanasse GJ. Prevalence of 25-hydroxyvitamin $D$ deficiency in subgroups of elderly persons with anemia: Association with anemia of inflammation. Blood. 2011; 117(10):2800-6. http://dx.doi.org/10.1182/ blood-2010-09-309708

8. Patel NM, Gutiérrez OM, Andress DL, Coyne DW, Levin A, Wolf M. Vitamin D deficiency and anemia in early chronic Kidney disease. Rev Kidney Int. 2010; 77(8):715-20. http://dx.doi.org/10.1038/ki. 2009.551

9. Han SS, Kim M, Kim H, Lee SM, Oh YJ, Lee JP, et al. Non-Linear relationship between Serum 25-hydroxyvitamin D and hemoglobin in Korean females: The Korean national health and nutrition examination survey 2010-2011. Plos One. 2013; 8(8):1-7. http://dx.doi.org/10.1371/journal.pone. 0072605
10. Yoo EH, Cho HJ. Prevalence of 25-Hydroxyvitamin $D$ Deficiency in Korean patients with anemia. J Clin Lab Anal. 2014; 29(2):129-34. http://dx.doi.org/ 10.1002/jcla.21740

11. Alon DB, Chaimovitz C, Dvilansky A, Lugassy G, Douvdevani $A$, Shany $S$, et al. Novel role of 1 , $25(\mathrm{OH})(2) \mathrm{D}(3)$ in induction of erythroid progenitor cell proliferation. Exp Hematol. 2002; 30(5):403-9. http://dx.doi.org/10.1016/\$0301-472X(02)007890

12. Santoro D, Caccamo D, Lucisano D, Buemi $M$, Sebekova K, Teta D, et al. Interplay of vitamin D, erythropoiesis, and the renin-angiotensin system. Bio Med Res Int. 2015; 1(1):1-11. http://dx.doi.org/ 10.1155/2015/145828

13. Norman AW. Minireview: Vitamin D receptor: New assignments for an already busy receptor. Endocrinology. 2006; 147(12):5542-8. http://dx. doi.org/10.1210/en.2006-0946

14. Reichel H, Koeffler HP, Norman AW. The role of the vitamin $D$ endocrine system in health and disease. N Engl J Med. 1989; 320(15):980-91. http:// dx.doi.org/10.1056/NEJM198904133201506

15. Meguro S, Tomita M, Katsuki T, Kato K, Oh H, Ainai $A$, et al. Plasma 25-Hydroxyvitamin $D$ is independently associated with hemoglobin concentration in male subjects with type 2 diabetes mellitus. Int J Endocrinol. 2011; 1(1):1-5. http:// dx.doi.org/10.1155/2011/362981

16. Hirani V, Cumming RG, Blyth F, Naganathan V, Couteur DGL, Waite LM, et al. Cross-sectional and longitudinal associations between the active vitamin D metabolite (1,25 dihydroxyvitamin D) and haemoglobin levels in older Australian men: The concord health and ageing in men Project. Age. 2015; 37(8):1-13. http://dx.doi.org/10.1007/s11 357-015-9749-1

17. Schuch NJ, Garcia VC, Vívolo SR, Martini LA. Relationship between vitamin $D$ receptor gene polymorphisms and the components of metabolic syndrome. Nutr J. 2013; 12(96):1-7. http://dx.doi. org/10.1186/1475-2891-12-96

18. Sezer S, Tutal E, Bilgic A, Ozdemir FN, Haberal M. Possible influence of vitamin $D$ receptor gene polymorphisms on recombinant human erythropoietin requirements in dialysis patients. Transplant Proc. 2007; 39(1):40-4. http://dx.doi.org/10.1016/j. transproceed.2006.10.214

19. Amato M, Pacini S, Aterini S, Punzi T, Gulisano M, Ruggiero $M$. Iron Indices and vitamin $D$ receptor plymorphisms in hemodialysis patients. Adv Chronic Kidney Dis. 2008; 15(2):186-90. http://dx.doi.org/ 10.1053/j.ackd.2008.01.013 
20. Valdivielso JM, Fernandez E. Vitamin D receptor polymorphisms and diseases. Clin Chim Acta. 2006; 371(1-2):1-12. http://dx.doi.org/10.1016/j.cca. 2006.02.016

21. World Health Organization. Physical status: The use and interpretation of anthropometry. Geneva: WHO; 1995.

22. Cockcroft DW, Gault MH. Prediction of creatinine clearance from serum creatinine. Nephron. 1976; 16(1):31-41.

23. Aidar M, Line SR. A Simple and cost-effective protocol for DNA isolation from buccal epithelial cells. Braz Dent J. 2007; 18(2):148-52. http://dx.doi. org/10.1590/S0103-64402007000200012

24. Coutard A, Garlantézec R, Estivin S, Andro M, Gentric A. Association of vitamin D deficiency and anemia in a hospitalized geriatric population: Denutrition as a confounding factor. Ann Hematol. 2013; 92(5):615-9. http://dx.doi.org/10.1007/ s00277-012-1633-9

25. Sim JJ, Lac PT, Liu IL, Mequerditchian SO, Kumar VA, Kujubu DA, et al. Vitamin D deficiency and anemia: A cross-sectional study. Ann Hematol. 2010; 89(5):447-52. http://dx.doi.org/10.1007/ s00277-009-0850-3

26. Kiss Z, Ambrus C, Almasi C, Berta K, Deak G, Horonyi $\mathrm{P}$, et al. Serum 25(OH)-cholecalciferol concentration is associated with hemoglobin level and erythropoietin resistance in patients on maintenance hemodialysis. Nephron Clin Pract. 2011; 117(4):373-8. http://dx.doi.org/10.1159/000 321521

27. Ertürk S, Kutlay S, Karabulut HG, Keven K, Nergizoglu G, Ates K, et al. The impact of vitamin $D$ receptor genotype on the management of anemia in hemodialysis patients. Am J Kidney Dis. 2002; 40(4):816-23. http://dx.doi.org/10.1053/ajkd. 2002.35694

28. Finkelstein JL, Mehta S, Duggan C, Spiegelman D, Aboud S, Kupka R, et al. Predictors of anaemia and iron deficiency in HIV-infectedpregnant women in Tanzania: A potential role for vitamin D and parasitic infections. Public Health Nutr. 2012; 15(5):928-937. http://dx.doi.org/10.1017/S1368980011002369

29. Zittermann A, Kuhn J, Dreier J, Knabbe C, Prokop S, Gummert JF, et al. Association of 25-hydroxyvitamin D with anemia risk in patients scheduled for cardiac surgery. Int J Lab Hematol. 2014; 36(1):29-36. http://dx.doi.org/10.1111/ijlh. 12112

30. Meguro S, Tomita M, Katsuki T, Kato K, Oh H, Ainai $A$, et al. Plasma 25-Hydroxyvitamin $D$ is independently associated with hemoglobin concentration in male subjects with type 2 diabetes mellitus. Int J Endocrinol. 2011; 1(1):1-5. http://dx. doi.org/10.1155/2011/362981

31. Liu T, Zhong S, Liu L, Liu S, Li X, Zhou T, et al. Vitamin $D$ deficiency and the risk of anemia: A metaanalysis of observational studies. Ren Failure. 2015; 17(6):929-34. http://dx.doi.org/10.3109/08860 22X.2015.1052979

32. Smith EM, Tangpricha V. Vitamin D and anemia: Insights into an emerging association. Curr Opin Endocrinol Diabetes Obes. 2015; 22(6):432-8. http://dx.doi.org/10.1097/MED.0000000000 000199
Received: October 5, 2015 Final version: May 4, 2016 Approved: June 6, 2016 